\title{
Erratum to: Automatic change detection in vision: Adaptation, memory mismatch, or both? II: Oddball and adaptation effects on event-related potentials
}

\author{
Flóra Bodnár ${ }^{1,2}$ • Domonkos File ${ }^{1,2,3}$ • István Sulykos ${ }^{1,2,3}$ • Krisztina Kecskés-Kovács ${ }^{1}$. \\ István Czigler ${ }^{1,2}$
}

Published online: 18 September 2017

(C) The Psychonomic Society, Inc. 2017

Erratum to: Atten Percept Psychophys

https://doi.org/10.3758/s13414-017-1373-y

In the published article (on page 3, first paragraph, top) there is an incorrect citation: "File, Bodnár, Sulykos, Kecskés-Kovács \& Czigler, 2017". The correct citation would be:

"File, File, Bodnár, Sulykos, Kecskés-Kovács \& Czigler, 2017". In the Reference list it should read: "File, D., File, B., Bodnár, F., Sulykos, I., Kecskés-Kovács, K., \& Czigler, I.(2017).Visual mismatch negativity (vMMN) for low- and high-level deviances: A control study. Atten Percept Psychophys. doi: 10.3758/s13414-017-1373-y).

The online version of the original article can be found at https://doi.org/ 10.3758/s13414-017-1402-x

Domonkos File

file.domonkos@ttk.mta.hu

1 Centre for Natural Sciences, Institute of Cognitive Neuroscience and Psychology, HAS, P.O. Box 286, Budapest 1519, Hungary

2 Institute of Psychology, Eötvös Loránd University, Budapest, Hungary

3 Doctoral School of Psychology, Eötvös Loránd University, Budapest, Hungary 